\title{
PENGARUH PENDIDIKAN, JUMLAH PENDUDUK DAN UMR TERHADAP JUMLAH PENGANGGURAN DI PROVINSI RIAU 2010-2020
}

\author{
Aswanto ${ }^{1}$ \\ ${ }^{1}$ Universitas Riau \\ aswanto.feuir@gmail.com
}

\begin{abstract}
ABSTRAK
Persoalan pengangguran menjadi pekerjaan rumah seluruh wilayah di Indonesia, hal tersebut karena dengan tingginya angka pengangguran tentunya akan mendorong persoalan lainnya tidak hanya ekonomi tetapi juga sosial. Maka masalah pengangguran menjadi prioritas kebijakan dalam menangani persoalan perekonomian, termasuk Provinsi Riau. Pendidikan merupakan modal bagi sumber daya manusia yang dapat meningkatkan kemampuan baik secara formal maupun keterampilan, sehingga lebih memudahkan sumber daya manusia dalam mencari pekerjaan karna mempunyai nilai daya saing yang tinggi dan berakibat pada berkurang nya jumlah pengangguran Provinsi Riau. Penelitian ini bertujuan untuk mengkaji pengaruh tingkat pendidikan terhadap jumlah orang menganggur di Provinsi Riau. Kajian ini dianalisis dengan menggunakan analisis statistic deskriptif dan analisis regresi sederhana. Hasil kajian ini menemukan bahwa tingkat pendidikan berpengaruh negatif dan signifikan terhadap jumlah pengangguran, jumlah penduduk berpengaruh negatif dan signifikan terhadap jumlah pengangguran sedangkan Upah Minimum Regional berpengaruh positif dan signifikan terhadap jumlah pengangguran Provinsi Riau 20102020.
\end{abstract}

Kata Kunci: Tingkat Pendidikan, Penduduk, Upah Minimum Regional, Jumlah Pengangguran

\begin{abstract}
The problem of unemployment becomes homework in all regions in Indonesia, this is because with the high unemployment rate will certainly encourage other problems not only economic but also social. So the issue of unemployment becomes a policy priority in dealing with economic issues, including Riau Province. Education is a capital for human resources that can improve the ability both formally and skill, making it easier for human resources to find work because it has a high competitiveness value and results in a reduced number of unemployed Riau Province. This study aims to examine the influence of education levels on the number of unemployed people in Riau Province. The study was analyzed using descriptive statistical analysis and simple regression analysis. The results of this study found that the level of education has a negative and significant effect on the number of unemployed, the number of residents has a negative and significant effect on the number of unemployed while the Regional Minimum Wage has a positive and significant effect on the number of unemployed riau province 2010-2020.
\end{abstract}

Keywords: Education Level, Population, Regional Minimum Wage, Number of Unemployed 

Prosiding The 1st National Conference on Applied Business, Education, \& Technology (NCABET)"

Unversitas Bina Bangsa 2021

DOI Article : $10.46306 /$ ncabet.v1i1.5

PENDAHULUAN

Masalah pengangguran memang selalu menjadi suatu persoalan yang perlu dipecahkan dalam perekonomian khususnya di negara berkembang seperti Indonesia. Jumlah penduduk yang terus bertambah setiap tahun membawa akibat peningkatan jumlah angkatan kerja dan tentunya akan berakibat pada kebutuhan akan lowongan kerja yang meningkat pula.

Menurut Sukirno (2015) pengangguran adalah keadaan kekurangan yang dialami oleh individu dan tidak mendapatkan pekerjaan atau sedang mencari pekerjaan. Dalam arti luas mendeskripsikan bahwa pengangguran adalah usia tenaga kerja yang pasif dalam memproduksi dan menghasilkan barang atau jasa. Pengangguran adalah suatu hal yang ditakuti dan tidak dikehendaki bagi setiap individu. Penyebab pegangguran pada umumnya karena jumlah angkatan kerja atau pencari kerja tidak sebanding dengan lapangan pekerjaan yang ada.

Persoalan pengangguran di Provinsi Riau, tentunya merupakan persoalan yang sangat di perhatikan, pada saat jumlah pengangguran meningkat maka akan menjadi persoalan yang harus di pecahkan akibat beban ekonomi yang di tanggung daerah. Peningkatan jumlah penduduk tentunya akan mendorong meningkatnya para pencari kerja atau angkatan kerja yang selanjutnya akan menciptakan persaingan dalam pencarian kerja.

Berikut ini dapat di lihat perkembangan jumlah pengangguran di Provinsi Riau tahun 20102020 :

Tabel 1.1 Jumlah Pengangguran di Provinsi Riau Tahun 2010-2020

\begin{tabular}{|c|c|}
\hline Tahun & $\begin{array}{c}\text { Pengangguran } \\
\text { (Jiwa) }\end{array}$ \\
\hline 2010 & 207.247 \\
\hline 2011 & 149.941 \\
\hline 2012 & 109.650 \\
\hline 2013 & 143.817 \\
\hline 2014 & 176.762 \\
\hline 2015 & 217.053 \\
\hline 2016 & 222.006 \\
\hline 2017 & 184.564 \\
\hline 2018 & 192.801 \\
\hline
\end{tabular}




\begin{tabular}{|l|l|}
2019 & 190.143 \\
\hline 2020 & 203.837 \\
\hline
\end{tabular}

Sumber: Badan Pusat Statistik Provinsi Riau, 2021

Berdasarkan tabel 1.1 di ketahui bahwa perkembangan jumlah pengangguran di Provinsi Riau cenderung berfluktuasi, terlihat pada tahun 2011 dan 2012 mengalami penurunan, akan tetapi tahun 2014 dan 2015 kembali mengalami peningkatan. Dan selama kurun waktu 2010 hingga 2020 jumlah pengangguran di Provinsi Riau menunjukkan trend yang positif atau cenderung meningkat.

Dalam teori Klasik Adam Smith menjelaskan pandangan nya bahwa pengangguran dapat dicegah melalui sisi penawaran (Gilarso, 2004) yang artinya pengangguran tidak akan terjadi jika pihak penawaran tenaga kerja dapat memperbaiki kualitasnya, banyak indikator yang menilai kualitas sumber daya manusia atau tenaga kerja salah satunya yaitu pendidikan tenaga kerja itu sendiri.

Menurut Todaro dan Smith (2013) pendidikan merupakan salah satu jalan pembekalan ilmu yang dapat digunakan untuk meningkatkan kualitas sumber daya manusia. Peran penting pendidikan dalam kemajuan pembangunan ekonomi adalah dapat mengurangi tingkat pengangguran dan meningkatkan kesejahteraan masyarakatnya. Salah satu indikator untuk menggambarkan tingkat pendidikan pada masyarakat adalah dengan rata-rata lama sekolah. Selain pendidikan, jumlah penduduk dan upah minimum regional juga dapat mempengaruhi jumlah pengangguran di Provinsi Riau.

Tabel 1. 2 Pendidikan, Penduduk, Upah Minimum Regional (UMR) Riau 2010-2020

\begin{tabular}{|c|c|c|c|}
\hline Tahun & $\begin{array}{c}\text { Pendidikan (Rata-rata } \\
\text { Lama Sekolah) }\end{array}$ & Penduduk & UMR \\
\hline 2010 & 8.25 & 5574928 & 1016000 \\
\hline 2011 & 8.29 & 5726241 & 1120000 \\
\hline 2012 & 8.34 & 5879109 & 1238000 \\
\hline 2013 & 8.38 & 6033268 & 1400000 \\
\hline 2014 & 8.47 & 6188442 & 1700000 \\
\hline 2015 & 8.49 & 6344402 & 1878000 \\
\hline 2016 & 8.59 & 6500971 & 2095000 \\
\hline 2017 & 8.76 & 6657911 & 2266722 \\
\hline
\end{tabular}


Prosiding The 1st National Conference on Applied Business, Education, \& Technology (NCABET)"

Unversitas Bina Bangsa 2021

DOI Article : $10.46306 /$ ncabet.v1i1.5

\begin{tabular}{|l|l|l|l|}
2018 & 8.92 & 6814909 & 2464154 \\
\hline 2019 & 9.03 & 6971745 & 2662025 \\
\hline 2020 & 9.14 & 7128305 & 2888563 \\
\hline
\end{tabular}

Sumber: Badan Pusat Statistik Provinsi Riau, 2021

Berdasarkan tabel 1.2 dapat dilihat perkembangan rata-rata lama sekolah di Provinsi Riau, dimana jika di lihat perkembangannya cenderung selalu meningkat, dan menunjukkan trend yang positif. Yang artinya selama kurun waktu 2010 hingga 2020 terjadi peningkatan pendidikan di Provinsi Riau. Dimana sumber daya manusia di Provinsi Riau menempuh pendidikan yang lebih tinggi yang artinya semakin meningkat pula kualitas sumber daya manusianya.

Sesuai dengan pernyataan Todaro dan Smith (2013) menjelaskan bahwa pendidikan memiliki hubungan negatif dengan penganguran. Semakin meningkatnya lama pendidikan yang terlihat dari rata-rata lama sekolah, maka akan meningkatkan kualitas sumber daya manusia yang selanjutnya menekan pengangguran. Namun yang terjadi kenyataannya justru berlawanan dengan pernyataan tersebut, pada saat rata-rata lama sekolah cenderung memiliki trend positif tetapi jumlah pengangguran juga memiliki trend yang positif.

Jumlah penduduk dalam pembangunan ekonomi suatu daerah merupakan permasalahan mendasar. Karena pertumbuhan penduduk yang tidak terkendali dapat mengakibatkan tidak tercapainya tujuan pembangunan ekonomi yaitu kesejahteraan rakyat. Melihat table 1.2 menunjukkan bahwa jumlah penduduk Provinsi Riau dari tahun 2010 sebesar 5574928 jiwa sampai 2020 sebesar 7128305 jiwa sehingga mengalami peningkatan, maka akan dapat mempengaruhi jumlah pengangguran.

Berdasarkan tabel 1.2 dapat diketahui bahwa upah minimum regional Provinsi Riau memiliki trend yang positif, yaitu memiliki kecenderungan yang meningkat. Yang mana dapat dilihat selama kurun waktu 2010 hingga 2020 upah minimum regional Provinsi Riau terus mengalami peningkatan. Pada tahun 2010 upah minimum regional Provinsi Riau sebesar Rp1.016.000 meningkat hingga tahun 2020 menjadi Rp2.888.563. Di jelaskan dalam kurva Phillips yang mana pada saat upah meningkat maka akan mendorong penurunan pengangguran. Tetapi kondisi yang terjadi di Provinsi Riau justru sebaliknya, pada saat upah meningkat, jumlah pengangguran juga mengalami peningkatan.

\section{METODE PENELITIAN}

a. Sumber data 
Sumber data utama yang digunakan dalam penelitian ini adalah data sekunder dan diperoleh melalui data pada publikasi website resmi Badan Pusat Statistik (BPS) Provinsi Riau

b. Variabel penelitian

Adapun penjelasan dari variabel penelitian yang digunakan dalam penelitian ini adalah:

1. Jumlah Pengangguran adalah penduduk umur 15 tahun ke atas yang tidak bekerja namun sedang mencari pekerjaan atau sedang mempersiapkan suatu usaha baru atau penduduk yang tidak mencari pekerjaan karena sudah diterima bekerja tetapi belum mulai bekerja, dalam satuan jiwa (BPS 2021)

2. Tingkat pendidikan diwakili dengan rata-rata lama sekolah (RLS). Rata-rata lama sekolah adalah rata-rata jumlah tahun yang dihabiskan oleh penduduk yang berusia 15 tahun ke atas untuk menempuh semua jenis pendidikan formal yang pernah dijalani atau sedang dijalani, dengan satuan tahun (BPS 2021)

3. Penduduk adalah semua orang yang berdomisili di wilayah geografis Republik Indonesia selama 6 bulan atau lebih dan atau mereka yang berdomisili kurang dari 6 bulan tetapi bertujuan untuk menetap, dengan satuan Jiwa (BPS 2021)

4. Upah minimum regional (UMR) adalah suatu standar minimum yang digunakan oleh para pengusaha untuk memberikan upah kepada pegawai, karyawan, atau buruh di dalam lingkungan usaha atau kerjanya. UMR yang dimaksud adalah Upah Minimum Kabupaten/Kota/Provinsi tahun 2020, dalam satuan Rupiah (BPS 2021)

c. Teknik analisis data

Teknik yang digunakan dalam penelitian ini adalah deskriptif untuk mendeskripsikan suatu gejala, peristiwa, dan kejadian yang terjadi secara faktual, dan data kuantitatif yang berbentuk angka. Dimana penelitian ini menggunakan alat analisis regresi linier berganda yang digunakan untuk mengetahui pengaruh variabel bebas terhadap variabel terikat. Dengan menggunakan aplikasi Eviews 10. Adapun Bentuk persamaannya sebagai berikut :

$$
\mathrm{Y}=\alpha+\beta 1 \mathrm{X} 1+\beta 2 \mathrm{X} 2+\beta 3 \mathrm{X} 3+\varepsilon
$$

Dimaana:

$$
\begin{array}{ll}
\mathrm{Y} & =\text { Jumlah Pengangguran } \\
\alpha & =\text { Konstanta } \\
\beta 1 & =\text { Nilai Koefisien Regresi } \\
\mathrm{X} 1 & =\text { Pendidikan }
\end{array}
$$


Prosiding The 1st National Conference on Applied Business, Education, \& Technology (NCABET)"

Unversitas Bina Bangsa 2021

DOI Article : $10.46306 /$ ncabet.v1i1.5

$$
\begin{array}{ll}
\mathrm{X} 2 & =\text { Penduduk } \\
\mathrm{X} 3 & =\mathrm{UMR} \\
\varepsilon & =\text { Term of Error }
\end{array}
$$

\section{a. Teori Pengangguran}

Pengangguran adalah masalah makroekonomi yang mempengaruhi manusia secara langsung dan merupakan yang paling berat. Kebanyakan orang kehilangaan pekerjaan berarti penurunan standar kehidupan dan tekanan psikologis. Jadi tidaklah mengejutkan jika pengangguran menjadi topik yang sering dibicarakan dalam perdebatan politik dan para politis sering mengklaim bahwa kebijakan yang mereka tawarkan akan membantu menciptakan lapangan kerja (Mankiw, 2006).

Sukirno (2008) mengklasifikasikan pengangguran berdasarkan cirinya, dibagi menjadi empat kelompok :

\section{1) Pengangguran Terbuka}

Pengangguran ini adalah tenaga kerja yang sungguh-sungguh tidak mempunyai pekerjaan. Pengganguran jenis ini cukup banyak karena memang belum mendapat pekerjaan padahal telah berusaha secara maksimal dan sebagai akibat pertambahan lowongan pekerjaan yang lebih rendah daripada pertambahan tenaga kerja.

Efek dari keadaan ini di dalam suatu jangka masa yang cukup panjang mereka tidak melakukan suatu pekerjaan. Jadi mereka menganggur secara nyata dan separuh waktu, dan oleh karenaya dinamakan pengangguran terbuka. Pengangguran terbuka dapat pula wujud sebagai akibat dari kegiatan ekonomi yang menurun, dari kemajuan teknologi yang mengurangi penggunaan tenaga kerja, atau sebagai akibat dari kemunduran perkembangan suatu industri.

\section{2) Pengangguran Tersembunyi}

Pengangguran ini adalah tenaga kerja yang tidak bekerja secara optimal karena suatu alasan tertentu. Salah satunya adalah karena kecilnya perusahaan dengan tenaga kerja yang terlalu banyak sehingga untuk menjalakan kegiatannya tidak efisien. Kelebihan tenaga kerja yang digunakan digolongkan dalam pengangguran tersembunyi.

3) Setengah Menganggur

Pengangguran ini adalah tenaga kerja yang tidak bekerja secara optimal karena tidak ada lapangan pekerjaan, biasanya tenaga kerja setengah menganggur ini merupakan tenaga kerja yang bekerja kurang dari 35 jam selama seminggu. Mereka mungkin hanya bekerja 
satu hingga dua hari dalam seminggu, atau satu hingga empat jam sehari. Pekerja-pekerja yang mempunyai masa kerja seperti ini digolongkan sebagai setengah menganggur.

\section{4) Pengangguran Bermusim}

Pengangguran ini adalah tenaga kerja yang tidak bekerja karena terikat pada musim tertentu. Pengangguran seperti ini terutama di sektor pertanian dan perikanan. Pada umumnya petani tidak begitu aktif di antara waktu sesudah menanam dan panen. Apabial dalam masa tersebut mereka tidak melakukan pekerjaan lain maka mereka terpaksa menganggur.

\section{b. Pendidikan}

Todaro dan Smith (2013) mengungkapkan bahwa modal manusia dapat diinvestasikan melalui bidang pendidikan dan kesehatan. Pendidikan memainkan peran penting dalam hal kemampuan suatu perekonomian untuk mengadopsi teknologi modern dan membangunan sebuah kapasitas bagi pertumbuhan yang berkelanjutan. Dengan demikian, pendidikan dan kesehatan bisa juga dilihat sebagai komponen vital dalam pertumbuhan dan pembangunan, sebagai input bagi fungsi produksi agregat.

Berdasarkan Undang-Undang Republik Indonesia nomor 20 tahun 2003 pasal I tentang sistem pendidikan nasional, pendidikan adalah usaha sadar dan terencana untuk mewujudkan suasana belajar dan proses pembelajaran agar peserta didik secara aktif mengembangkan potensi dirinya untuk memiliki kekuatan spiritual keagamaan, pengendalian diri, kepribadian, kecerdasan, akhlak mulia, serta keterampilan yang diperlukan dirinya, masyarakat, bangsa dan Negara. Menurut Sirilius (2017) pendidikan adalah cara yang tepat dalam meningkatkan kualitas sumber daya manusia. Pendidikan ini dapat dilihat melalui Indikator rata - rata lama sekolah yang mengindikasikan tingginya tingkat pendidikan yang dicapai oleh masyarakat di suatu daerah. Semakin tinggi rata - rata lama sekolah menunjukkan semakin tinggi jenjang pendidikan seseorang maka secara umum semakin tinggi pula kualitas seseorang, baik pola pikir maupun pola tindakannya.

Jenjang Pendidikan Tertinggi yang Ditamatkan adalah jenjang pendidikan tertinggi yang ditamatkan oleh seseorang, yang ditandai dengan sertifikat/ijazah.

1. SD meliputi Sekolah Dasar, Madrasah Ibtidaiyah dan sederajat.

2. SMP meliputi jenjang pendidikan SMP Umum, Madrasah Tsanawiyah, SMP kejuruan dan sederajat. 
Prosiding The 1st National Conference on Applied Business, Education, \& Technology (NCABET)"

Unversitas Bina Bangsa 2021

DOI Article : $10.46306 /$ ncabet.v1i1.5

3. SMA meliputi jenjang pendidikan Sekolah Menengah Atas (SMA), sekolah menegah kejuruan (SMK), Madrasah Aliyah dan sederajat.

4. Perguruan Tinggi (PT) meliputi jenjang pendidikan Diploma I, II, III dan IV dan sederajat. Pendidikan merupakan salah satu bentuk modal manusia (Human Capital) yang menunjukkan kualitas Sumber Daya Manusia (SDM). Bahwa orang yang memiliki tingkat pendidikan lebih tinggi, diukur dengan lamanya waktu untuk sekolah dan akan memiliki pekerjaan dan upah yang lebih baik dibandingkan dengan orang yang pendidikannya lebih rendah (BPS, 2020).

Rata-rata lama sekolah adalah rata-rata jumlah tahun dihabiskan oleh penduduk yang berusia 15 tahun ke atas untuk menempuh semua jenis pendidikan formal yang pernah dijalani Batas maksimum untuk rata-rata lama sekolah adalah 15 tahun dan batas minimum sebesar 0 tahun (standar UNDP). Batas maksimum 15 tahun mengindikasikan tingkat pendidikan maksimum yang ditargetkan adalah setara Sekolah Menengah Atas (BPS, 2020).

\section{c. Penduduk}

Jumlah penuduk yang semakin meningkat diikuti dengan jumlah angkatan kerja yang meningkat akan meningkatkan jumlah pengangguran apabila tidak diimbangi dengan peningkatan kesempaan kerja. Menurut Arsyad (2004:268) definisi penduduk adalah orang yang tinggal di desa, kota dan sebagainya. Jumlah penduduk dapat di pandang sebagai faktor pendukung pembangunan sebab dengan pertambahan penduduk berarti juga pertambahan tenaga kerja yang dapat meningkatkan produksi dan memperluas pasar. Menurut Becker human capital adalah bahwa manusia bukan sekedar sumber daya namun merupakan modal yang menghasilkan pengembalian dan setiap pengeluaran yang dilakukan dalam rangka mengembangkan kualitas dan kuantitas modal tersebut merupakan kegiatan investasi (Atmanti, 2005).

\section{d. Upah Minimum Regional (UMR)}

Upah dalam teori Ekonomi diartikan sebagai pembayaran atas jasajasa fisik maupun mental yang disediakan oleh tenaga kerja kepada para pengusaha. Teori Ekonomi tidak membedakan diantara pembayaran kepada pegawai tetap dengan pembayaran keatas jasa-jasa pekerja kasar dan tidak tetap. Kedua jenis pendapatan pekerja (pembayaran kepada pekerja) disebut dengan upah (Sukirno, 2015). Setiap pekerja atau buruh berhak memperoleh penghasilan yang memenuhi penghidupan yang layak bagi manusia, oleh karena itu pemerintah menetapkan kebijakan pengupahan yang melindungi pekerja atau buruh yang meliputi : 

a. Upah Minimum
b. Upah kerja lembur
c. Upah tidak masuk kerja karena berhalangan
d. Upah tidak masuk kerja karena melakukan kegiatan lain diluar pekerjaan
e. Upah karena menjalankan hak waktu istirahat kerjanya

\section{HASIL DAN PEMBAHASAN}

Analisis data dalam penelitian ini bertujuan untuk mengetahui pengaruh Pendidikan, terhadap Jumlah orang menganggur di Provinsi Riau tahun 2010-2020. Metode analisis data yang digunakan dalam penelitian ini adalah dengan regresi sederhana melalui aplikasi eviews 10. Berdasarkan hasil regresi maka diperoleh persamaan sebagai berikut :

\section{Tabel 1.3 Hasil Olahan Data}

Dependent Variable: Y

Method: Least Squares

Date: 09/23/21 Time: 17:36

Sample: 20102020

Included observations: 11

\begin{tabular}{ccccc}
\hline \hline \multicolumn{1}{c}{ Variable } & Coefficient & Std. Error & t-Statistic & Prob. \\
\hline \hline C & 4840127. & 831929.8 & 5.817951 & 0.0007 \\
X1 & -228844.9 & 70792.27 & -3.232625 & 0.0144 \\
X2 & -0.607554 & 0.122258 & -4.969442 & 0.0016 \\
X3 & 0.619364 & 0.105360 & 5.878576 & 0.0006 \\
\hline \hline R-squared & 0.870344 & Mean dependent var & 181620.1 \\
Adjusted R-squared & 0.814777 & S.D. dependent var & 34466.06 \\
S.E. of regression & 14833.34 & Akaike info criterion & 22.32243 \\
Sum squared resid & $1.54 \mathrm{E}+09$ & Schwarz criterion & 22.46712 \\
Log likelihood & -118.7734 & Hannan-Quinn criter. & 22.23122 \\
F-statistic & 15.66300 & Durbin-Watson stat & 3.093031 \\
Prob(F-statistic) & 0.001733 & & \\
\hline \hline
\end{tabular}


Prosiding The 1st National Conference on Applied Business, Education, \& Technology (NCABET)"

Unversitas Bina Bangsa 2021

DOI Article : 10.46306/ncabet.v1i1.5

Sumber : Hasil olahan data

Uji Linearitas Regresi

a. Uji Koefisien Determinasi

\begin{tabular}{|c|c|}
\hline R-squared & 0.870344 \\
\hline Adjusted R-squared & 0.814777 \\
\hline
\end{tabular}

Sumber : Output Pengolahan Data

Dari hasil perhitungan diperoleh Koefisien Determinasi atau $\left(\mathrm{R}^{2}\right)$ dalam penelitian ini sebesar 0,8147 atau 81,47\%, artinya pengaruh Pendidikan (X1), Penduduk (X2), Upah Minimum Regional (X3) sebesar 81,47\% dan sisanya 18,53\% dipengaruhi oleh variabel lain yang tidak diteliti

\section{b. Uji simultan (Uji F)}

\begin{tabular}{|c|c|}
\hline F-statistic & 15.66300 \\
\hline Prob(F-statistic) & 0.001733 \\
\hline
\end{tabular}

Sumber : Output Pengolahan Data

Berdasarkan tabel 1.3 diatas dapat diketahui nilai signifikan Uji F atau Uji Simultan sebesar 0,001 lebih kecil dari 0,05, yang artinya secara bersama - sama Pendidikan (X1), Jumlah Penduduk (X2), Upah Minimum Regional (X3), berpengaruh signifikan terhadap Jumlah Pengangguran (Y) di Provinsi Riau.

\section{c. Uji Parsial (Uji t)}

\begin{tabular}{|c|c|c|c|c|}
\hline Variable & Coefficient & $\begin{array}{c}\text { Std. } \\
\text { Error }\end{array}$ & $\begin{array}{c}\mathrm{t}- \\
\text { Statistic }\end{array}$ & Prob. \\
\hline C & 4840127 & 831929.8 & 5.817951 & 0.0007 \\
\hline X1 & -228845 & 70792.27 & -3.23263 & 0.0144 \\
\hline
\end{tabular}




\begin{tabular}{|l|l|l|l|l|}
$\mathrm{X} 2$ & -0.60755 & 0.122258 & -4.96944 & 0.0016 \\
\hline $\mathrm{X} 3$ & 0.619364 & 0.10536 & 5.878576 & 0.0006 \\
\hline
\end{tabular}

Sumber : Output Pengolahan Data

Dari hasil persamaan tersebut dapat dijelaskan sebagai berikut :

1. Pendidikan menunjukkan bahwa berpengaruh negatif terhadap pengangguran di Riau dengan nilai $(-228844,9)$ artinya ketika pendidikan meningkat maka jumlah pengangguran akan berkurang begitu juga sebaliknya. Sejalan dengan teori nya yang mengatakan hubungan pendidikan dengan tingkat pengangguran hubungan negatif.

2. Penduduk menunjukkan bahwa berpengaruh negatif terhadap pengangguran di Riau dengan nilai $(-0,607)$ artinya ketika penduduk meningkat maka jumlah pengangguran akan berkurang begitu juga sebaliknya.

3. Upah minimum regional menunjukkan bahwa berpengaruh positif terhadap jumlah pengangguran di Riau dengan nilai $(0,619)$ artinya ketika upah minimum regional meningkat maka jumlah pengangguran akan bertambah, begitu juga ketika jumlah pengangguran berkurang maka upah minimum regional juga berkurang.

\section{KESIMPULAN}

Berdasarkan hasil penelitian data serta pembahasan dalam penelitian ini, maka dapat ditarik kesimpulan bahwa :

1. Pendidikan memiliki pengaruh negatif dan signifikan dengan taraf signifikasi $95 \%(\alpha=5 \%)$ terhadap jumlah penganguran di Provinsi Riau Tahun 2010-2020. Artinya peningkatan tingkat pendidikan akan mengurangi jumlah pengangguran dan penurunan tingkat pendidikan akan menambah jumlah pengangguran di Provinsi Riau.

2. Penduduk memiliki pengaruh negatif dan signifikan dengan taraf signifikasi $95 \%(\alpha=5 \%)$ terhadap jumlah penganguran di Provinsi Riau Tahun 2010-2020. Artinya peningkatan penduduk akan mengurangi jumlah pengangguran dan penurunan penduduk akan menambah jumlah pengangguran di Provinsi Riau.

3. Upah minimum regional (UMR) memiliki pengaruh positif dan signifikan dengan taraf signifikasi 95\% ( $\alpha=5 \%)$ terhadap jumlah pengangguran di Provinsi Riau Tahun 2010-2020. Artinya peningkatan upah minimum regional akan meningkatkan jumlah pengangguran dan penurunan upah minimum regional akan menurunkan jumlah pengangguran di Provinsi Riau 
Prosiding The 1st National Conference on Applied Business, Education, \& Technology (NCABET)"

Unversitas Bina Bangsa 2021

DOI Article : $10.46306 /$ ncabet.v1i1.5

\section{DAFTAR PUSTAKA}

Data Pendidikan, Upah Minimum Regional, Produk Domestik Regional Bruto, Tingkat Pertumbuhan Ekonomi dan Jumlah Pengangguran Provinsi Riau 2010-2020, Badan Pusat Statistik.

Ernawaningtyas Liya. 2021. Analisis Pengaruh PDRB, Pendidikan dan UMP terhadap Pengangguran di Provinsi Pulau Jawa 2011-2019. Fakultas Ekonomi dan Bisnis Islam. Institut Agama Islam Negeri Ponorogo.

Hartanto. Analisis Pengaruh Jumlah Penduduk, Pendidikan, Upah Minimum dan PDRB terhadap Jumlah Pengangguran Provinsi Jawa Timur 2010-2014. Jurnal Ilmu Ekonomi Terapan. Fakultas Ekonomi dan Bisnis Universitas Airlangga. Surabaya Hasanah Erni Umi. 2013. Ilmu Ekonomi Makro. Yogyakarta : CAPS Imarotus Suaidah, Hendry Cahyono., 2012, Pengaruh Tingkat Pendidikan Terhadap Tingkat Pengangguran di Kabupaten Jombang, dalam Jurnal Fakultas Ekonomi Unesa, Surabaya Jhingan. 2014. Ekonomi Pembangunan dan Perencanaan. Jakarta : Rajagrafindo Persada 